\title{
THE ENVIRONMENTAL ACCOUNTABILITY OF EFFICIENCY EVALUATION OF PROCESSING TECHNOGENIC FORMATIONS ${ }^{1}$
}

The article considers the possibility of using production induced resources as raw materials for production of metals. Theoretical approaches to the concept of damage from environmental pollution due to industrial activity are investigated. The economic and environmental justification of the feasibility of using technologies for processing of metallurgical raw materials is given.

Mining and smelting complex is one of the first sectors of Russian industry, which started radical modernization on its own, long before it was announced to be the main priority of Russian economic development. This industrial sector began to remove inefficient production by implementing programs dedicated to enhancing resource base, increasing technological capacity and improving productivity. Nowadays Russian metallurgical industry is developing by consolidation of mineral assets within the holding companies and by establishing of production facilities to manufacture products with high added value, such as galvanized and color bars, steel with polymer coating, plate and special types of large diameter pipes, etc. Nevertheless, the identification of promising directions for development and the role of metallurgy in the process of renovation of the entire economic system are of interest, because modernization is not just a technological innovation, but rather a change in the overall development concept.

Mining and metallurgical industry is a core sector of material production. At the same time it is a massive source of environmental pollution. Environmental damage from the activities of mining companies is made up of emissions of harmful substances, wastewater discharge, damaging natural ecosystems due to development of mineral deposits, as well as the placement of production induced waste. Environmental measures applied nowadays (the neutralization of sewage, installation of gas treatment, solid waste storage) do not radically solve the problem. A significant portion of emis-

\footnotetext{
${ }^{1}$ The paper was prepared within the Programme of the Russian Academy of Sciences № 24 «Scientific foundations of innovative energy-resource-saving environmentally-friendly technologies for assessment and development of natural and production induced resources».
}

sions still falls into the environment and polluting effects of industrial waste landfills extend in a radius of dozens of kilometers from the place of storage. Therefore, there is a need to assess the environmental damage caused by mining and metallurgical enterprises and to develop technologies to reduce it.

However, it should be noted that the term «damage» in economic science has still not received a clear definition. In this case, the whole set of methods developed to assess damage caused to the environment by anthropogenic influence, does not have sufficient theoretical justification, since the generally accepted approach to treatment of damage as a fundamental category is missing. In various sources, damage is defined as a synonym to harm, a kind of loss, the totality of the adverse effects of any impacts, the evaluation of injuries incurred, etc. Comprehensive Dictionary of Economics [1] gives the following definition of damage: «1) losses, unforeseen costs, loss of property and money, benefit shortfalls; 2) the harm caused by the activities of one economic entity to other entities or nature, environment, people». Much of the normative documents regulating the so-called environmental law in Russia, the concept of harm and damage to the environment are used as identical (for example, in the Federal Law «On Environmental Protection», in Forest, Land and Water Code). This also confirms the lack of clear universally accepted concept of damage.

Some authors [8], [9] tend to develop a general theoretical approach to the definition of damage and give a methodical support for its reasonable economic evaluation. Thus, in [8] damage is defined as «the cumulative effect of the negative impact to the economy, expressed in value». This statement is especially noteworthy because it highlights the economic dimension of the problems of damage assessment. Many authors [4], [5], [6], [7], [8], [9] emphasize the importance of economic evaluation of damage caused to the environment, and damage caused by environmental violations is generally defined as «interest on ecological debt» [9]. Economic damage from environmental pollution is defined in some studies [6] as the monetary evaluation of natural aggregate damage: for material objects, health and 
living standards, for industries and natural resource system. It is noted that some part of damage cannot be directly expressed in monetary form, as embodied in what is called a loss of aesthetic qualities, reduced quality of life and the deterioration of the environment for future generations. The category of economic loss from environmental violations, discussed in [9], reflects the impact of changes in the environment only on economic processes. There is also noted that the economic impact from environmental violations is manifested in two forms: reduced revenue (from the use of natural goods) and forced consumption (costs for compensation of the damage). The need to protect the environment from adverse effects and the need to redress the damage is recognized by modern society. However, the implementation mechanisms of the relevant measures are still far from being perfect. Therefore, it is the economic science that has to develop economic tools to address environmental problems.

Despite the lack of theoretical foundation, due to its practical significance, the damage from environmental pollution is a well methodologically studied area. At present the database analysis of techniques used to assess the environment damage amounts to hundreds of sources. The analysis of these methods allowed revealing the following deficiencies:

1) Lack in methodological literature of welldefined interpretation of the term damage and of the object that is subject to damage.

2) Discrepancy between the assessment methods and spread of damage in dynamics, lack of period for calculating of damages.

3) Lack of comprehensive study which should take into consideration damage caused by the interaction of different kinds of objects of natural and anthropogenic environment.

Without diminishing the importance of existing methods to assess damage to the environment, we shall note that the main purpose of their creation is to calculate the amount of money that will be recovered from the economic entity that has committed environmental violations, in favor of the government structures.

As a generalization, it should be noted that the natural environment is undergoing certain objective changes, i.e. changes that don't depend on the subject of study and can be recorded according to some parameters. When changing of these parameters is characterized by people as negative, we can speak about harm caused to the environment. Damage, in its turn, occurs as an estimate of indirect effect of changes in the environment on socio-economic processes. In other words, the damage to the environment is measured by environmental indicators; damage to the economy is measured by economic indicators. It should be emphasized that the damage cannot be regarded as a purely economic category, due to the fact that it characterizes the interaction of anthropogenic and natural environment.

Due to the complexity and uniqueness of the interaction of natural and production induced environment, the overall damage is a category that includes not only direct quantitative estimates, but also a variety of systemic effects. Accordingly, the total damage from one or another form of human impact should be considered as a synergistic set of economic and environmental damage:

$$
\mathrm{D}_{\text {total }}=\mathrm{D}_{\text {econ }}+\mathrm{D}_{\text {ecol }} \text {, }
$$

$\mathrm{D}_{\text {econ }}$ - economic damage, defined as the assessment of harm inflicted for socio-economic system; $\mathrm{D}_{\text {ecol }}$ - ecological damage, defined as the assessment of harm inflicted for nature; $\mathrm{D}_{\text {total }}$ - total damage.

In this case, the main criterion for the economic damage will be the cost of resources needed to compensate for the damage, and for the environmental damage the main criterion is the time needed for self-healing system. We shall also emphasize that consideration of these components of the total damage from human impacts is possible only in their systemic relationship.

Thus, in this article, special attention is paid to new technologies in mining and metallurgical production aiming to reduce the damage caused by anthropogenic impacts, and to increase economic and environmental efficiency. Lately, due to the growing shortage of ores and concentrates in the mining and metals sector, interest in technologies for the processing of production induced raw materials has arisen. Stockpiles of industrial waste are a valuable source of extraction of some components, while they are a source of environmental pollution. Therefore, the recycling of production induced structures, in addition to expanding the resource base, may be one of the ways to solve environmental problems. The value of metallurgical waste is already recognized by many metallurgical enterprises that by now involve the most promising raw materials into manufacture. For example, steel factories are using technology for processing mill scale and blast-furnace slag. Slag smelting furnaces are used for re-extraction of copper, zinc, gold 
and silver in the factories of nonferrous metallurgy. Technology for processing zinc cakes is used in zinc factories. Institute of Metallurgy (Russian Academy of Sciences) together with Chelyabinsk Zinc Plant has developed a technology that allows the use of electric furnace dust, which is a waste product of steel, containing $25 \%$ zinc, to produce zinc metal. In accordance with the information of Chelyabinsk Zinc Plant (hereinafter - CZP), the proportion of zinc oxide in total recycling is at the level of 3.8\% (4 190 t.). To date, the total need of the plant in the secondary raw materials is 13500 tons and it will grow in the future. According to the projection of CZP to 2020, it will be 20000 tons per year. This need can be fully satisfied with the processing of zinc-containing dusts in obtaining zinc oxide.

The author of the study carried out calculations on aggregated assessment of the economic efficiency of processing zinc-containing metallurgical raw materials in CZP. The following conditions were taken for calculations:

1) annual processing volume of dust -4000 tons (at the level of current needs in such kind of raw material);

2) zinc-containing dusts with the content of $15 \% \mathrm{Zn}$ are processed in welz-furnace CZP to give zinc oxide containing $50 \% \mathrm{Zn}$;

3 ) the resulting zinc oxide is sent in leach department CZP and further on the existing technology is brought to the metal;

4) through extraction of zinc from dust to zinc metal $-87,4 \%$;

5) commodity products is zinc metal in amount of 524,4 tons / year;

6) rated lifetime of the project -5 years.

Evaluating the effectiveness conducted in accordance with «Guidelines for the evaluation of investment projects» [7]. For purposes of this calculation, the price of zinc metal accepted is 2250 USD / t. (67 $500 \mathrm{rub} . / \mathrm{t}$.), the price of electric furnace dust $-2900 \mathrm{rub}$. / t. (price accepted at the rate of purchases at Cherepovets Metallurgical Plant, including railway transportation in gondola cars to CZP). Technical and economic indicators of electric furnace steelmaking dust recycling in order to obtain zinc are listed in Table 1.

Since the purpose of this study is to estimate only the economic efficiency of processing of metallurgical dusts for zinc, we have assumed in this calculation, that the production of zinc metal is equal to the volume of sales. Taking into consideration that the recycling of dust will be produced on existing
Table 1

Basic technical and economic indicators of technologies for processing steel dust for zinc

\begin{tabular}{|l|c|c|}
\hline \multicolumn{1}{|c|}{ Name of indicator } & units of measure & value \\
\hline $\begin{array}{l}\text { The volume of processing steel } \\
\text { dust }\end{array}$ & t/year & 4000 \\
\hline Zinc content of processed dust & $\%$ & 15 \\
\hline & t/year & 600 \\
\hline $\begin{array}{l}\text { Trans-extraction of zinc from } \\
\text { the dust to metal }\end{array}$ & USD/t & 2250 \\
\hline $\begin{array}{l}\text { The price of zinc accepted for } \\
\text { the calculations }\end{array}$ & rub./t & 67500 \\
\hline & t/year & 524,4 \\
\hline Output of commodities & mil. rub./year & 35,397 \\
\hline zinc metal & &
\end{tabular}

equipment of the plant, the investment costs consist of $R \& D$ costs in amount of 2,050 mil. rub. and current capital formation at a rate of 1,194 mil. rub. For the calculation it is assumed that the period of the research on implementation of technologies for processing electrosmelting-furnaces dust planned sales volume will be at the level of $75 \%$. After successful completion of the development work, production and sales volume will be $100 \%$. Own means are the financing source. Consumption of auxiliary materials and energy is set on the basis of specific indicators of the cost of zinc CZP, adjusted for the volume of processing 4000 tons of dust per year. The cost structure of the metallurgical processing of dust in obtaining metallic zinc is presented in Table 2. The largest share in the structure represents the cost of raw materials (44\%), energy and fuel (18\%) and shop expenses.

Key performance indicators of implementation of technologies for processing of metallurgical dusts for the extraction of zinc are presented in Table 3. According to our calculations, the total cost of processing dusts will be 26,187 mil. rub. per year, revenues from sales of marketable products in year of reaching full capacity will be 35,397 mil. rub. per year, net profit from processing $4000 \mathrm{t}$. dust reaches 5,654 mil. rub. per year. Investment costs are recouped in the first year of processing technology. Discounted cash flow over 5 years of the project will amount to 15,112 mil. rub. Budget effectiveness of the project is designed based on the amount of tax payments. Annual payments to the federal budget will amount to $0,778 \mathrm{mil}$. rub./year, in the regional budget 1,530 mil. rub./year. Thus, the above data suggest that economic efficiency and financial viability of the proposed technology is proved. 
Table 2

Total production cost of zinc from metallurgical dusts CZP

\begin{tabular}{|l|c|c|}
\hline \multicolumn{1}{|c|}{ Name of indicator } & $\begin{array}{c}\text { Total production } \\
\text { cost, mil. rub. }\end{array}$ & $\begin{array}{c}\text { Per unit } \\
\text { costs, rub./t }\end{array}$ \\
\hline Raw (dust) & 11,600 & 22121 \\
\hline Auxiliary materials & 1,790 & 3414 \\
\hline Energy and fuel & 4,813 & 9179 \\
\hline $\begin{array}{l}\text { Wages of the main } \\
\text { production personnel }\end{array}$ & 0,547 & 1044 \\
\hline $\begin{array}{l}\text { Allocations to non- } \\
\text { budgetary funds }\end{array}$ & 0,146 & 278 \\
\hline Shop costs & 4,501 & 8584 \\
\hline Actual manufacturing cost & 23,398 & 44620 \\
\hline Commercial expenses & 822 & 1568 \\
\hline General running costs & 1966 & 3749 \\
\hline Total production cost & 26187 & 49937 \\
\hline
\end{tabular}

Key performance indicators of recycling zinc-containing metallurgical dusts

\begin{tabular}{|l|c|c|}
\hline \multicolumn{1}{|c|}{ Name of indicator } & Unit of measure & Value \\
\hline Rated lifetime of the project & years & 5 \\
\hline $\begin{array}{l}\text { Output of commodities (zinc } \\
\text { metal) }\end{array}$ & t / year & 524,4 \\
\hline The need for investment & mil.rub & 3,244 \\
\hline The discount rate & mil. rub./year & 26,187 \\
\hline Full cost & rub./ t & 49,9 \\
\hline Unit cost of processing dust & mil. rub./ year & 35,397 \\
\hline Proceeds from the sale of & mil. rub. / year & 7,155 \\
\hline Profit before tax & mil. rub./year & 5,724 \\
\hline Net profit & years & 0,5 \\
\hline Payback period & mil. rub. & 15,112 \\
\hline Net Present Value & & \\
\hline Fiscal efficiency & mil. rub./year & 0,778 \\
\hline to the federal budget & mil. rub./year & 1,530 \\
\hline To the regional budget & \multicolumn{2}{|c|}{} \\
\hline
\end{tabular}

The calculated values prevented damage

\begin{tabular}{|l|c|}
\hline \multicolumn{1}{|c|}{ Name of indicator } & Value, mil.rub. \\
\hline $\begin{array}{l}\text { Prevented damage from soil and land } \\
\text { degradation, caused by waste disposal }\end{array}$ & 71,240 \\
\hline $\begin{array}{l}\text { Savings fee for waste disposal (reduction } \\
\text { damage from chemical pollution) }\end{array}$ & 0,800 \\
\hline Economic assessment of damage prevented & 72,040 \\
\hline
\end{tabular}

In addition to solving the problems of diversification of raw materials, improvement of the efficiency and complexity of the use of raw materials, processing of production induced structures raises a number of issues relating to negative environmental impacts. Thus, plants producing metallurgical waste (in our case, dust, enriched with zinc), bear the costs associated with their placement, as well as harm the environment, causing its contamination. Processing of metallurgical waste, obviously, should lead to reduction in harmful effects so any assessment of the effect of prevention of damage is of considerable interest from an environmental point of view. In the study of economic efficiency of processing of production induced structures, the prevented damage shall be regarded as an indicator of the effectiveness of the considered technologies. Thus, the total damages associated with the processing of zinc-containing metallurgical waste, which can be prevented will consist of:

1) prevented damage from the placement of industrial waste;

2) saving the cost for waste disposal, which is an estimate of the damage caused by land contamination by chemicals.

In this case, due to the lack of methodological tools for assessing all systemic effects, the calculation will be limited to the valuation of damage. Table 4 gives the indicators of economic damage that would be prevented when implementing the proposed technology. Thus, indicators of damage prevented were calculated on the basis of the valuation variables to prevent damage from soil and land degradation, and land pollution by chemicals, in accordance with the «Temporary method for determining prevented environmental damage» [3].

Thus, prevented damage from soil degradation will be 71,240 mil. rub., the savings pay for waste disposal will be 0,800 mil. rub., the total amount prevented damage will reach 72,040 rubles. Without going into detail on methods of calculation the indicators of prevented damage in the present study, as they are described in detail in «Temporary method...», we shall particularly note the following. Though the calculated economic assessment of prevented damage from processing of production induced structures is based on a number of assumptions and is incomplete, it is comparable and even at times exceeds the net income derived from the introduction of technology. Therefore, the establishment of viable technologies that will effectively recycle the accumulated technological fields is an essential factor to address environmental problems of mining and smelting complex.

In terms of real economic production of material goods is almost always associated with damage to the environment. For example, mining and metallurgical industry, being a major supplier of construction materials for the sphere of social production, is 
also a massive source of pollution. Environmental degradation in areas located the largest companies of the industry suggests that the emphasis in the development of mining and metallurgical complex should be placed on an adequate assessment and reduction of damage. Inflection point in the direction of maximizing profits at the expense of the environment, leads to deterioration of the effectiveness of the entire socio-economic system. Therefore, a fundamental condition for effective development is to achieve an optimal balance between the achieved wealth and the injury suffered.

\section{References:}

1. Borisov A. B. Comprehensive Dictionary of Economics. - M.: World of Books, 2003.

2. «Temporary typical method of estimating the economic efficiency of environmental activities and assess the economic damage to the national economy of environmental pollution» (approved by Decree of Gosplan, the USSR State Construction Committee, 10.21.1983). [Electronic resource] Access from ref.legal system «Consultant Plus».
3. «Temporary method of estimating prevented ecological damage» (approved by the Russian Federation State Committee for Environmental Protection). - M., 1999.

4. Evaluation of ecological and economic damage (methods and practices) / Khilchenko N. V., Lebedev, Y. V., Kopylova Y. Y., et. al. — Ekaterinburg: IE, Ural Division of RAS, 2004.

5. Pakhomov V. P., Ignatieva M. N., Litvinova A. A. Methodological position to assess damage from technogenic disasters mining character. - Ekaterinburg: IE, Ural Division of RAS, 2006.

6. Pakhomova N. V., Richter K. K. Economics of Natural Resources and Environmental Management. - Publishing office of St.-Petersburg State University, 1999.

7. Semyachkov A. I., Ignatieva M. N., Litvinova A. A. Identification and typology of the effects of mining complexes on the environment. - Ekaterinburg: IE, Ural Division of RAS, 2008.

8. Tulupov A. S. The theory of damages. - Moscow: Nauka, 2009.

9. Rumina E. V. Economic analysis of damage from environmental violations. - Moscow: Nauka, 2009.

\section{UDC 658.009.02: 338.33}

keywords: mining and smelting complex, environmental damage, industrial waste, zinc, assessment of economic and environmental efficiency 